\title{
Rodzice uczniów kształcących się w klasach integracyjnych - ich motywy i oczekiwania
}

\begin{abstract}
Przybyszewska Dominika, Parents of children studying in integrated classes - their motives and expectations [Rodzice uczniów kształcących się w klasach integracyjnych - ich motywy i oczekiwania]. Interdyscyplinarne Konteksty Pedagogiki Specjalnej, nr 6, Poznań 2014. Pp. 49-68. Adam Mickiewicz University Press. ISBN 978-83-232-2900-1. ISSN 2300-391X.
\end{abstract}

Integrated classes are one of the possible forms of education student with a disability. They are considered as an alternative to mass classes and special classes. Opinions about their functioning are often different. Also, there are a variety of reasons for choosing this form of education for the child. The article presents the results of a survey among parents of children studying in integrated classes in the city of Poznan. The aim was ascertain the reasons for parents to choose schools inclusive; getting to know the parents' expectations and to determine the degree of their fulfillment.

KEY WORDS: student with a disability, integration, the expectations of parents, choice of schools

System oświaty w Polsce zakłada istnienie szkół specjalnych, klas specjalnych, szkół integracyjnych, klas integracyjnych oraz szkół i klas ogólnodostępnych. Te ostatnie często zwane są masowymi. Do wszystkich wymienionych typów klas czy szkół mogą uczęszczać uczniowie ze specjalnymi potrzebami edukacyjnymi. 
W roku szkolnym 2013/2014 uczniów z orzeczeniem o potrzebie kształcenia specjalnego $\mathrm{w}$ szkołach podstawowych było 36,5 tys., z czego w oddziałach integracyjnych kształciło się $38,4 \% 1$.

Klasy integracyjne organizowane są dla dzieci i młodzieży z następującymi rodzajami niepełnosprawności: deficytami słuchu (osoby niesłyszące i słabosłyszące), deficytami wzroku (niewidome, słabowidzące), niepełnosprawnością ruchową, niepełnosprawnością intelektualną, autyzmem, zespołem Aspergera, niepełnosprawnościami sprzężonymi ${ }^{2}$ oraz dla uczniów niedostosowanych społecznie i zagrożonych niedostosowaniem społecznym ${ }^{3}$. Uczniowie ci mogą kształcić się w szkole podstawowej do końca roku szkolnego w roku kalendarzowym, w którym kończą 18. rok życia, natomiast $\mathrm{w}$ przypadku gimnazjum do roku, w którym kończą 21. rok życia, a w szkole ponadgimnazjalnej do 23. roku życia ${ }^{4}$.

Przepisy regulujące istnienie klas integracyjnych określają liczbę osób, która może się $w$ nich kształcić. Wynosi ona od 15 do 20 uczniów, w tym od 3 do 5 uczniów z niepełnosprawnością. Co ważne, jeśli u ucznia występuje niepełnosprawność złożona, można zmniejszyć liczbę osób w klasie o dwie ${ }^{5}$. W klasie integracyjnej za-

1 Główny Urząd Statystyczny, Oświata i wychowanie w roku szkolnym 2013/2014, Zakład Wydawnictw Statystycznych, Warszawa 2014, s. 91, 154.

${ }^{2}$ Rozporządzenie z dnia 17 listopada 2010 r. w sprawie warunków organizowania kształcenia, wychowania i opieki dla dzieci i młodzieży niepełnosprawnych oraz niedostosowanych społecznie w przedszkolach, szkołach i oddziałach ogólnodostępnych lub integracyjnych, § 1 .

${ }^{3}$ Rozporządzenie z dnia 17 listopada 2010 r. w sprawie warunków organizowania kształcenia, wychowania i opieki dla dzieci i młodzieży niepełnosprawnych oraz niedostosowanych społecznie w przedszkolach, szkołach i oddziałach ogólnodostępnych lub integracyjnych, § 2 .

${ }^{4}$ Rozporządzenie z dnia 17 listopada 2010 r. w sprawie warunków organizowania kształcenia, wychowania i opieki dla dzieci i młodzieży niepełnosprawnych oraz niedostosowanych społecznie $\mathrm{w}$ przedszkolach, szkołach i oddziałach ogólnodostępnych lub integracyjnych, § 3 .

${ }^{5}$ Rozporządzenie Ministra Edukacji Narodowej z dnia 21 maja 2001 r. w sprawie ramowych statutów publicznego przedszkola oraz publicznych szkól, zał. nr $2, \S 5$. 
trudnia się dodatkowo nauczyciela wspomagającego. Powinien on posiadać kwalifikacje z zakresu pedagogiki specjalnej6.

Program edukacyjny w klasie integracyjnej jest taki sam, jak w klasie ogólnodostępnej. Inne są natomiast metody, formy i środki nauczania. Jedynie dzieci $\mathrm{z}$ niepełnosprawnością intelektualną w stopniu głębszym realizują odrębny program nauczania ${ }^{7}$.

Do szkoły integracyjnej czy klasy integracyjnej w placówce ogólnodostępnej na poziomie szkoły podstawowej i gimnazjum dziecko przyjmowane jest na wniosek jego rodziców/prawnych opiekunów, przy czym:

1) dzieci z niepełnosprawnością na podstawie orzeczenia o potrzebie kształcenia specjalnego,

2) dzieci pełnosprawne na podstawie takich samych przepisów, jak w sytuacji rekrutacji do szkół ogólnodostępnych - stosuje się przepisy art. 2-5 Rozporządzenia Ministra Edukacji Narodowej i Sportu z dnia 20 lutego 2004 r. w sprawie warunków i trybu przyjmowania uczniów do szkół publicznych oraz przechodzenia z jednych typów szkół do innych.

Rodzice dziecka z niepełnosprawnością po uzyskaniu orzeczenia o potrzebie kształcenia specjalnego stają przed wyborem placówki dla swojego dziecka. Mogą wybrać szkołę/klasę specjalną, szkołę/klasę integracyjną, klasą ogólnodostępną8.

Klasa integracyjna musi spełniać wiele warunków, aby właśnie tam dziecko $\mathrm{z}$ niepełnosprawnością mogło $\mathrm{w}$ sposób pełny rozwijać

${ }^{6}$ Rozporządzenie Ministra Edukacji Narodowej z dnia 17 listopada 2010 r. w sprawie warunków organizowania kształcenia, wychowania i opieki dla dzieci i młodzieży niepełnosprawnych oraz niedostosowanych społecznie w przedszkolach, szkołach i oddziałach ogólnodostępnych lub integracyjnych, § 6 .

7 Rozporządzenie Ministerstwa Edukacji Narodowej z dnia 7 lutego 2012 r. w sprawie ramowych planów nauczania w szkołach publicznych.

${ }^{8}$ Szczegółowy opis poszczególnych instytucji oświatowych, w których moga kształcić się uczniowie z niepełnosprawnością, można odnaleźć w: A. Twardowski, Pomoc rodzinom dzieci niepetnosprawnych, [w:] I. Obuchowska (red.), Dziecko niepetnosprawne w rodzinie, WSiP, Warszawa 2008, s. 548-555 oraz D. Gorajewska (red.), Wsparcie dziecka $z$ niepetnosprawnościa $w$ rodzinie i szkole, Stowarzyszenie Przyjaciół Integracji, Warszawa 2008. 
swoje umiejętności i zdobywać wiedzę. Oczywiście musi być przystosowana pod względem infrastruktury i pomocy dydaktycznych, które pomogą uczniowi poznawać otaczający świat. Należy zauważyć, że przygotowania nie polegają tylko na stworzeniu odpowiedniego miejsca - to tak naprawdę jest to element najłatwiejszy. Wiele, jeśli nie najwięcej, zależy od przygotowania nauczyciela, rodziców oraz samego ucznia.

W przypadku szkół z klasami integracyjnymi konieczne jest nie tylko przygotowanie ucznia o specjalnych potrzebach, ale również uczniów pełnosprawnych. Edukacja integracyjna nie może opierać się na przypadku, ale na przemyślanym oddziaływaniu, w którym niebagatelną rolę odgrywają rodzice. Nastawienie opiekunów dziecka, ich postawy wpływają w dużym stopniu na zachowania prezentowane przez dzieci. Edukacja integracyjna powinna być wtórna w stosunku do działań integracyjnych, które powinny rozpocząć się już w „w pierwszych latach życia dzieci, w rodzinie, kiedy jeszcze nie zostały ukształtowane i utrwalone negatywne postawy wobec mniej sprawnych" ${ }^{\prime 2}$. Ważne są zatem motywy wyboru szkoły integracyjnej przez rodziców. Wybór placówki oświatowej powinien być przemyślaną i świadomą decyzją. Z motywami wiążą się nieodzownie oczekiwania względem szkoły.

\section{Oczekiwania rodziców}

Rodzice formułują wiele oczekiwań zróżnicowanych ze względu na ich treść i rodzaj. Dorota Zawadzka wskazuje na istnienie oczekiwań wobec nauczyciela (by był osobą z bardzo dobrym przygotowaniem i wysokimi umiejętnościami interpersonalnymi), oczekiwań wobec szkoły (głównie dotyczą warunków, które mogą zagwarantować dziecku bezpieczeństwo i umożliwią wszechstronny

${ }^{9}$ Z. Kazanowski, B. Mazur, Samoocena młodzieży niepetnosprawnej intelektualnie w stopniu lekkim jako wyznacznik integracji społecznej, [w:] G. Dryżałowska, H. Żuraw (red.), Integracja społeczna osób niepetnosprawnych, Wyd. Akademickie "Żak”, Warszawa 2004, s. 170. 
rozwój), oczekiwań wobec bazy szkolnej (w szczególności w aspekcie nowoczesnego wyposażenia klas lekcyjnych, liczebności uczniów w oddziale oraz racjonalnego obciążenia uczniów nauką w ciągu tygodnia), oczekiwań dotyczących relacji nauczyciela z dzieckiem (w zakresie indywidualizacji), oczekiwań związanych z kontaktem między nauczycielami a rodzicami ${ }^{10}$. Jolanta Rafał-Łuniewska na podstawie indywidualnych rozmów z rodzicami wskazała na istnienie następujących oczekiwań głównych opiekunów dziecka:

- „indywidualnego podejścia do dziecka;

- rzetelnych informacji o działaniach szkoły;

- nauczania samodzielności, korzystania z różnych źródeł informacji;

- sprawiedliwego podejścia do ucznia;

- rozwijania uzdolnień i zainteresowań ucznia;

- pomocy w przezwyciężaniu trudności, akceptacji dziecka;

- wskazania metod skutecznego uczenia się;

- życzliwej atmosfery;

- profesjonalizmu nauczyciela, wykwalifikowanej kadry nauczycieli i specjalistów;

- rozwijania samodzielności u dzieci;

- wyposażenia dziecka w operacyjną wiedzę i umiejętności;

- zapewnienia bezpieczeństwa dziecku;

- sprzyjania rozwojowi osobowości;

- różnorodnej oferty zajęć pozalekcyjnych;

- pozytywnych oddziaływań wychowawczych;

- sprawiedliwego traktowania dziecka;

- udzielania pomocy w trudnych sytuacjach;

- zauważania inności dziecka i odpowiednich działań;

- bogatej bazy dydaktycznej"11.

${ }^{10}$ D. Zawadzka, Biblioteczka refleksyjnego praktyka. Nauczyciele $i$ rodzice - sprzymierzeńcy w edukacji $i$ wychowaniu, <http://www.praktykinauczycielskie.dsw.edu. pl/wp-content/uploads/2011/03/Seminarium_D.Zawadzka_06_05.pdf>, s. 12-13, [dostęp: 28.05.2015].

${ }^{11} \mathrm{~J}$. Rafał-Łuniewska, Wspieranie dziecka ze specjalnymi potrzebami edukacyjnymi razem - rodzice i szkoła, Ośrodek Rozwoju Edukacji, Warszawa, <www.zsl-goraj.cil. pl/dokumenty/wdsp.pdf>, s. 30-31, [dostęp: 28.05.2015]. 
Zauważa się, iż rodzice uczniów uczący się w klasach integracyjnych mają wiele obaw dotyczących tego rodzaju kształcenia. Rodzice uczniów z niepełnosprawnością mogą uznawać szkołę integracyjną lub masową jako najlepszą opcję kształcenia, która pozwoli zaspokoić potrzeby emocjonalne i społeczne ${ }^{12}$. Rodzice pełnosprawnych dzieci natomiast mogą uznawać, iż uczniowie $\mathrm{z}$ niepełnosprawnością będą faworyzowani, a na innych będzie ciążył obowiązek nieustannej pomocy. Dzieci pełnosprawne w opinii ich opiekunów mogą być narażone na ataki uczniów z niepełnosprawnością. Obawy mogą dotyczyć również niskiego poziomu nauczania ${ }^{13}$. Pokrywają się one $\mathrm{z}$ potocznymi opiniami o funkcjonowaniu klas integracyjnych ${ }^{14}$. $Z$ tego względu wśród czynników mających wpływ na wdrażanie inkluzji odnajdziemy właśnie: "omówienie obaw nauczycieli i rodziców [D.P.] dotyczących włączenia do klas uczniów ze specyficznymi trudnościami, zwłaszcza z zaburzeniami zachowania"15.

Z badań Zenona Gajdzicy wynikają następujące motywy wyboru placówki integracyjnej przez rodziców pełnosprawnych uczniów:

- uznanie, że klasa integracyjna spełnia warunki (dodatkowy nauczyciel, mniejsza liczebność klasy) zapewniające wyższy poziom kształcenia;

12 M. Rogalińska, „3D” w szkole masowej, a rzeczywistość, [w:] Z. Janiszewska-Nieścioruk (red.), Uczeń o specjalnych potrzebach edukacyjnych w przestrzeni wspótczesnego systemu edukacji, Oficyna Wydawnicza Uniwersytetu Zielonogórskiego, Zielona Góra 2010, s. 134-135; A. Twardowski, Dylematy integracyjnego ksztatcenia dzieci $i$ młodzieży z niepetnosprawnościa, [w:] Z. Janiszewska-Nieścioruk (red.), Problemy edukacji integracyjnej dzieci $i$ młodzieży z niepetnosprawnościq intelektualna, Oficyna Wydawnicza „Impuls”, Kraków 2007, s. 25.

${ }^{13}$ M. Rogalińska, „3D” w szkole masowej ..., dz. cyt., s. 134-135.

${ }_{14}$ Z. Gajdzica, Kategorie sukcesów w opiniach nauczycieli klas integracyjnych jako przyczynek do poszukiwania koncepcji edukacji integracyjnej, Oficyna Wydawnicza „Impuls”, Kraków 2014, s. 69.

15 A. Zamkowska, Modele wsparcia udzielanego uczniowi z niepetnosprawnościa w szkole inkluzyjnej - rozwiązania zagraniczne, [w:] Z. Janiszewska-Nieścioruk (red.), Uczeń o specjalnych potrzebach edukacyjnych w przestrzeni współczesnego systemu edukacji, Oficyna Wydawnicza Uniwersytetu Zielonogórskiego, Zielona Góra 2010, s. 109. 
- pozytywne opinie innych rodziców;

- aprobata idei integracji;

- uznanie, że dziecko nabędzie przydatnych doświadczeń oraz właściwych etycznie postaw życiowych;

- uznanie, iż klasa integracyjna stwarza lepsze warunki rozwoju dla dzieci z trudnościami w uczeniu się ${ }^{16}$.

Stanisława Mihilewicz w badaniach opinii rodziców dzieci uczących się w szkołach integracyjnych wskazała, że główni opiekunowie uznają, iż kształcenie integracyjne pozwala nauczyć się życzliwości dla innych, akceptacji, cierpliwości, wytrwałości, zdobyć większą świadomość równości ludzi między sobą, równości w zakresie dostępu do nauki oraz zwiększyć liczbę nowych doświadczeń17. Wyniki uzyskane przez Agnieszkę Żytę w badaniach, w których uczestniczyli rodzice uczniów z głębszą niepełnosprawnością intelektualną, wskazują, że $81 \%$ respondentów dostrzegło wiele szans $\mathrm{w}$ integracji osób z niepełnosprawnością intelektualną. Jednakże $77 \%$ badanych rodziców dostrzegło również różnego rodzaju zagrożenia. Przebywanie osób z niepełnosprawnością intelektualną ze sprawnymi rówieśnikami może zranić emocjonalnie uczniów z ograniczeniami sprawności poprzez poniżanie, wyśmiewanie, dokuczanie, agresję, izolację, lekceważenie ${ }^{18}$.

16 Z. Gajdzica, dz. cyt., s. 68.

${ }^{17}$ S. Mihilewicz, Postrzeganie integracji przez rodziców dzieci sprawnych $i$ niepetnosprawnych, [w:] Z. Kazanowski, D. Osik-Chudowolska (red.), Integracja osób niepetnosprawnych w edukacji i integracjach społecznych, Wyd. Uniwersytetu Marii Curie-Skłodowskiej, Lublin 2003, s. 339-340.

18 A. Żyta, Szanse i zagrożenia integracyjnego kształcenia i bytowania osób z głębsza niepetnosprawnością intelektualna, [w:] Z. Kazanowski, D. Osik-Chudowolska (red.), Integracja osób niepetnosprawnych w edukacji i integracjach społecznych, Wyd. Uniwersytetu Marii Curie-Skłodowskiej, Lublin 2003, s. 29-31; por.: M. Chodkowska, Razem damy sobie radę. W drodze do zintegrowanego społeczeństwa, WSiP, Warszaw 2009, s. 30-33; K. Ćwirynkało, Pozycja socjometryczna uczniów niepetnosprawnych a postawa nauczycieli wobec integracji, [w:] Z. Kazanowski, D. Osik-Chudowolska (red.), Integracja osób niepetnosprawnych w edukacji i integracjach społecznych, Wyd. Uniwersytetu Marii Curie-Skłodowskiej, Lublin 2003, s. 269-275. 
Powyżej opisane badania wskazują na istnienie różnorodnych oczekiwań rodziców. Mogą nimi kierować zróżnicowane motywy wyboru placówki integracyjnej czy klasy integracyjnej w szkole ogólnodostępnej.

\section{Problematyka badań własnych}

Punktem wyjścia badań własnych były rozważania na temat motywów wyboru szkoły i oczekiwań względem niej formułowanych przez rodziców. Przedstawiono dwa zasadnicze cele:

1. Zbadać motywy, jakimi kierowali się rodzice $\mathrm{w}$ wyborze szkoły integracyjnej.

2. Zbadać, w jakim stopniu w ocenie rodziców ich oczekiwania zostały spełnione.

Problemy główne określono następująco:

1. Co kierowało rodzicami w wyborze szkoły integracyjnej?

2. Jak rodzice oceniają stopień spełnienia swoich oczekiwań?

Problemy główne zostały uszczegółowione $\mathrm{w}$ następujący sposób:

1. Jakie czynniki zewnętrzne $\mathrm{w}$ opinii rodziców zadecydowały o wyborze szkoły integracyjnej?

2. Jakie czynniki wewnętrzne w opinii rodziców zadecydowały o wyborze szkoły integracyjnej?

3. Jakie były oczekiwania rodziców wobec kształcenia ich dzieci w placówkach integracyjnych?

4. W jakim stopniu $\mathrm{w}$ ocenie rodziców zostały spełnione ich oczekiwania?

5. Jakie czynniki, zdaniem rodziców, wiązały się z realizacją ich oczekiwań?

$\mathrm{W}$ badaniach zastosowano metodę sondażu diagnostycznego, a kwestionariusz ankiety $\mathrm{z}$ pytaniami półotwartymi stanowił narzędzie badawcze. Rodziców poproszono o udzielenie odpowiedzi na sześć pytań (trzy pytania zamknięte i trzy pytania półotwarte). 
Grupą badawczą stanowiło 70 osób - rodziców dzieci kształcących się w oddziałach integracyjnych w czterech różnych szkołach podstawowych na terenie miasta Poznania. Przekrój wiekowy badanych był następujący:

- od 25. do 34. roku życia - 14 respondentów, co stanowiło $20 \%$ osób;

- od 35. do 44. roku życia - 42 respondentów, co stanowiło $60 \%$ osób;

- powyżej 44. roku życia - 14 respondentów, co stanowiło $20 \%$ osób.

Respondenci legitymowali się następującym wykształceniem:

- podstawowym - 2 respondentów (2,86\% badanych);

- zawodowym - 12 respondentów (17,14\% badanych);

- średnim - 23 respondentów (32,86\% badanych);

- wyższym - 33 respondentów (47,14\% badanych).

\section{Omówienie wyników badań}

Do czynników zewnętrznych, które zadecydowały o wyborze szkoły oraz klasy integracyjnej dla swojego dziecka respondenci zaliczyli głównie (szczegółowe wyniki są zaprezentowane w tab. 1):

- rejon zamieszkania (ponad 60\% respondentów zaznaczyło tę odpowiedź);

- mniejsza liczba uczniów w klasie (prawie 65\%);

- pozytywne opinie innych $(70 \%$ respondentów zaznaczyło tę odpowiedź, w tym pozytywne opinie innych rodziców - prawie $40 \%$ oraz pozytywne opinie znajomych - trochę ponad $30 \%)$.

Mniej wskazań rodziców dotyczyło następujących kwestii:

- zatrudnionych specjalistów (psycholog, pedagog, pedagog specjalny, logopeda, rehabilitant) w szkole ( $10 \%$ respondentów);

- uczniowie z niepełnosprawnościami zbliżonymi do niepełnosprawności dziecka pod względem jej rodzaju (np. niedosłuch, 
niepełnosprawność intelektualna) oraz stopnia (np. niepełnosprawność intelektualna w stopniu lekkim) (trochę ponad 10\% respondentów);

- infrastruktury szkoły - dostosowanie budynków, stan budynków, rozkład istotnych pomieszczeń (prawie 15\%);

- olimpiad i konkursów, w których biorą udział uczniowie szkół, osiągając wysokie wyniki (20\%).

Tabela 1. Czynniki zewnętrzne mające wpływ na wybór szkoły

\begin{tabular}{|l|c|c|}
\hline \multirow{2}{*}{\multicolumn{1}{|c|}{ Czynniki zewnętrzne }} & \multicolumn{2}{c|}{ Razem } \\
\cline { 2 - 3 } & $n$ & {$[\%]$} \\
\hline Brak & 0 & 0 \\
\hline Rejon zamieszkania & 44 & 62,86 \\
\hline Łatwy dojazd & 19 & 27,14 \\
\hline Inne dzieci w szkole & 20 & 28,57 \\
\hline Znajomość nauczyciela & 16 & 22,86 \\
\hline Rodzice w szkole mają wpływ na różne sprawy & 16 & 22,86 \\
\hline Pozytywne opinie rodziców & 27 & 38,57 \\
\hline Pozytywne opinie znajomych & 22 & 31,43 \\
\hline Zajęcia dodatkowe & 18 & 25,71 \\
\hline Olimpiady i konkursy & 14 & 20,00 \\
\hline Wysokie wyniki egzaminów & 18 & 25,71 \\
\hline Inni uczniowie szkoły z podobną niepełnosprawnością & 8 & 11,43 \\
\hline Infrastruktura szkoły & 10 & 14,29 \\
\hline Mniejsza liczba uczniów & 45 & 64,29 \\
\hline Dostępna pomoc & 17 & 24,29 \\
\hline Zatrudnieni specjaliści & 7 & 10,00 \\
\hline
\end{tabular}

Opracowanie własne

Dla rodziców mniej istotna była jakość pracy w szkole oraz uzyskiwane przez dzieci wyniki (zaledwie co czwarty rodzic brał pod uwage ten czynnik, decydując o wyborze szkoły). Większość rodzi- 
ców kierowała się liczbą dzieci w klasie oraz faktem, że szkoła jest w rejonie, czyli względami formalnymi. Drugą grupę czynników uwzględnianych przez rodziców były opinie różnych osób o szkole oraz względy organizacyjne, na przykład łatwy dojazd lub fakt, iż w szkole uczy się także rodzeństwo. Niewiele osób (23\%) za ważną uznało możliwość wspólpracy $\mathrm{z}$ nauczycielem czy możliwość wpływania na życie szkoły.

Obok czynników zewnętrznych respondenci mieli wskazać czynniki wewnętrzne, które wpłynęły na wybór samej placówki oraz klasy integracyjnej dla swojego dziecka. Najczęściej rodzice uznawali następujące czynniki zewnętrzne mające wpływ na ich decyzje (szczegółowe wyniki są zaprezentowane w tab. 2):

- dziecko pozna możliwości pomagania innym (prawie $63 \%$ odpowiedzi);

- dziecko będzie umiało zachowywać się w towarzystwie osób z niepełnosprawnością (ponad 50\%);

- przekonania rodziców o równości wszystkich ludzi (ponad $45 \%)$;

- dziecko będzie traktowało innych w sposób życzliwy (ponad $45 \%)$;

- dziecko pozna problemy osób z niepełnosprawnością (ponad $45 \%)$.

Ponad połowa respondentów zaznaczyła odpowiedź: „Chciałam/em, aby moje dziecko umiało zachować się $\mathrm{w}$ towarzystwie osób z niepełnosprawnością, nie bało się ich, nie unikało". Jedynie co trzeci badany wskazał na: „Moje przekonanie o równości wszystkich ludzi (bez względu na stopień sprawności)". Najmniejszą rolę $\mathrm{w}$ podjęciu decyzji o wyborze szkoły odegrało życzenie rodziców dotyczące tego, by dziecko nauczyło się porozumiewać $\mathrm{z}$ nieznanymi sobie osobami. Ten czynnik zyskał jedynie trochę ponad $18 \%$ wszystkich wskazań. To znaczy, że jedynie prawie co drugi rodzic uznał go za istotny. Jest to zdecydowanie niższy wynik niż te uzyskane przez inne odpowiedzi. Warto zaznaczyć, że aż sześć wariantów otrzymało bardzo podobny procentowy (ponad $30 \%$ udział we wskazywanych czynnikach, czyli uznawał je za 
istotne około co trzeci badany. W porównaniu do czynników zewnętrznych odpowiedzi udzielane w tym pytaniu były zdecydowanie bardziej zrównoważone - różnice między kolejnymi wariantami nie są tak duże, jak w przypadku zewnętrznych uwarunkowań dokonania wyboru.

Tabela 2. Czynniki wewnętrzne mające wpływ na wybór szkoły

\begin{tabular}{|l|c|c|}
\hline \multirow{2}{*}{\multicolumn{2}{|c|}{ Czynniki wewnętrzne }} & \multicolumn{2}{c|}{ Razem } \\
\cline { 2 - 3 } & $n$ & {$[\%]$} \\
\hline Przekonania o równości wszystkich ludzi & 33 & 47,14 \\
\hline Przekonanie o idei integracji & 22 & 31,43 \\
\hline Dziecko będzie miało informacje o niepełnosprawności & 22 & 31,43 \\
\hline Dziecko pozna problemy osób z niepełnosprawnością & 32 & 45,71 \\
\hline Dziecko pozna możliwości pomagania innym & 44 & 62,86 \\
\hline Dziecko będzie empatyczne & 24 & 34,29 \\
\hline $\begin{array}{l}\text { Dziecko będzie umiało zachowywać się w towarzystwie osób } \\
\text { z niepełnosprawnością }\end{array}$ & 36 & 51,43 \\
\hline Dziecko będzie traktowało innych w sposób życzliwy & 32 & 45,71 \\
\hline Dziecko znajdzie przyjaciół & 23 & 32,86 \\
\hline Dziecko będzie samodzielne & 24 & 34,29 \\
\hline Dziecko zostanie zaakceptowane & 22 & 31,43 \\
\hline Dziecko nauczy się porozumiewać z nieznanymi sobie osobami & 13 & 18,57 \\
\hline Inne & 0 & 0 \\
\hline
\end{tabular}

Opracowanie własne

Również oczekiwania rodziców dotyczące przebiegu procesu kształcenia dziecka w szkole, podobnie jak czynniki, które miały wpływ na wybór placówki edukacyjnej, nie są jednorodne. Respondenci mieli możliwość wskazania swoich oczekiwań i oceny poziomu ich spełnienia.

Przy określaniu stopnia spełnienia oczekiwań brane były pod uwage dwa aspekty. Pierwszy określał liczbę możliwych wskazań 
w kafeterii dokonanych przez rodziców. Drugi stanowił ocenę spełnienia poszczególnych oczekiwań. Następnie, na podstawie uzyskanej średniej arytmetycznej, ustalono pięciostopniową skalę stopnia spełnienia oczekiwań. Mogły one zostać uznane za: niezrealizowane, minimalnie zrealizowane, zrealizowane $\mathrm{w}$ stopniu przeciętnym, zrealizowane $\mathrm{w}$ stopniu powyżej przeciętnym i zrealizowane w stopniu całkowitym.

Z oceny oczekiwań badanych rodziców wynika, że są oni raczej rozczarowani (szczegółowe wyniki są tab. 3). Ponad 75\% respondentów uznało swoje oczekiwania za niespełnione lub spełnione w minimalnym stopniu (przy czym pierwsza kategoria uzyskała ponad $25 \%$ wskazań, a druga $50 \%$ wskazań). Jedynie trochę ponad $7 \%$ rodziców deklaruje spełnienie ich oczekiwań przez placówkę edukacyjną w stopniu całkowitym. Wyniki te mogą wskazywać na niezadowolenie i rozczarowanie rodziców faktycznym funkcjonowaniem danej placówki edukacyjnej.

Tabela 3. Stopień spełnienia oczekiwań rodziców wobec placówki

\begin{tabular}{|l|c|c|}
\hline \multirow{2}{*}{ Stopień spełnienia oczekiwań } & \multicolumn{2}{c|}{ Razem } \\
\cline { 2 - 3 } & $n$ & {$[\%]$} \\
\hline Niezrealizowane & 17 & 24,29 \\
\hline Minimalny & 36 & 51,43 \\
\hline Przeciętny & 9 & 12,86 \\
\hline Powyżej przeciętny & 3 & 4,29 \\
\hline Całkowity & 5 & 7,14 \\
\hline
\end{tabular}

Opracowanie własne

Niektóre oczekiwania w opinii respondentów zostały spełnione całkowicie. Rodzice najczęściej wskazywali następujące aspekty pracy szkoły:

- uczniowie mogą zwrócić się do nauczyciela z każdym problemem ( $40 \%$ wszystkich wskazań);

- lekcje prowadzone są w sposób atrakcyjny (ponad 37\%); 
- uczniowie są traktowani w sposób sprawiedliwy przez nauczycieli (ponad 35\%).

Najmniej wskazań uzyskały następujące odpowiedzi:

- każde dziecko jest otoczone autentyczną troską ze strony rodziców, zatem główni opiekunowie każdego z uczniów w klasie będą poświęcać czas swoim dzieciom i nimi się interesować (jedynie niewiele ponad 11\% wskazań),

- szkoła zapewnia dobre przygotowanie do egzaminów końcowych (ponad 17\% wskazań).

Warto zauważyć, iż prawie $6 \%$ rodziców z grupy badawczej nie miało oczekiwań w stosunku do placówki, do której posłali swoje

Tabela 4. Oczekiwania rodziców wobec placówki ocenione jako w pełni spełnione

\begin{tabular}{|l|c|c|}
\hline \multirow{2}{*}{ Oczekiwania w pełni spełnione } & \multicolumn{2}{c|}{ Razem } \\
\cline { 2 - 3 } & $n$ & {$[\%]$} \\
\hline Brak & 4 & 5,71 \\
\hline Szeroka oferta zajęć pozalekcyjnych & 23 & 32,86 \\
\hline Dobre wyposażenie szkoły & 14 & 20,00 \\
\hline Włączenie dziecka z niepełnosprawnością w życie szkoły & 13 & 18,57 \\
\hline Atrakcyjne lekcje & 26 & 37,14 \\
\hline Sprawiedliwe traktowanie & 25 & 35,71 \\
\hline Dziecko ma możliwość zwrócenia się z prośbą o pomoc & 28 & 40,00 \\
\hline Szkoła nie będzie pogłębiać izolacji & 21 & 30,00 \\
\hline Wszyscy uczniowie uczestnikami życia szkolnego & 15 & 21,43 \\
\hline Atmosfera życzliwości & 22 & 31,43 \\
\hline Dobre przygotowanie do egzaminów & 12 & 17,14 \\
\hline Specjalistyczne zajęcia & 16 & 22,86 \\
\hline Kontakt z nauczycielem, specjalistą & 22 & 31,43 \\
\hline Atmosfera wzajemnej współpracy & 15 & 21,43 \\
\hline Najlepsi nauczycieli & 17 & 24,29 \\
\hline Autentyczna troska i pomoc ze strony rodziców & 8 & 11,43 \\
\hline Inne (dzieci będą mniej anonimowe) & 2 & 2,86 \\
\hline
\end{tabular}

Opracowanie własne 
dziecko. Również istotny jest fakt, że dwoje respondentów wskazało mniejszą anonimowość dziecka (prawie 3\% wskazań). Pozostałe możliwe odpowiedzi mieściły się $\mathrm{w}$ granicach od ponad $18,5 \%$ wskazań do prawie 33\%. Wszystkie odpowiedzi respondentów $\mathrm{w}$ aspekcie całkowicie spełnionych oczekiwań przedstawiono w tabeli 4.

Tabela 5. Czynniki, które w opinii rodziców sprzyjały spełnieniu ich oczekiwań

\begin{tabular}{|l|c|c|}
\hline \multirow{2}{*}{ Przyczyny spełnienia oczekiwań } & \multicolumn{2}{c|}{ Razem } \\
\cline { 2 - 3 } & $n$ & {$[\%]$} \\
\hline Oddani dzieciom nauczyciele & 49 & 70,00 \\
\hline Dobrze zorganizowana praca & 25 & 35,71 \\
\hline Współpraca z rodzicami & 32 & 45,71 \\
\hline Specjaliści & 25 & 35,71 \\
\hline Współpraca pracowników & 34 & 48,57 \\
\hline Dobra atmosfera & 41 & 58,57 \\
\hline Dobre wyposażenie szkoły & 16 & 22,86 \\
\hline Współpraca z organizacjami & 10 & 14,29 \\
\hline Rodzice angażują się w pracę szkoły & 24 & 34,29 \\
\hline Zajęcia dodatkowe & 28 & 40,00 \\
\hline
\end{tabular}

Opracowanie własne

Interesujące jest to, w czym rodzice upatrują spełnienia swoich oczekiwań. Respondenci wskazują wiele ich przyczyn (tab. 5), przede wszystkim:

- oddanych nauczycieli, którzy pracują w szkole (70\% wskazań);

- dobrą atmosferę panującą w szkole (prawie $60 \%$ );

- współpracę wszystkich pracowników dla dobra dziecka (prawie $50 \%$ );

- współpracę między pracownikami szkoły a rodzicami (trochę ponad $45 \%)$. 
Najmniejszy procent rodziców natomiast za przyczyny spełnienia swoich oczekiwań uznaje: współpracę szkoły z innymi partnerami - organizacjami porządku publicznego, instytucjami (niewiele ponad $14 \%$ ) oraz dobre wyposażenie placówki (prawie $23 \%$ ). Niepokojący może być fakt, iż rodzice oceniają bardzo nisko element tak zwanego partnerstwa edukacyjnego. Zaangażowanie wielu różnych podmiotów (np. poradnie, fundacje, stowarzyszenia, policja czy straż miejska) wpływają w dużym stopniu na efektywność oddziaływań wychowawczych na terenie placówki edukacyjnej. Tylko trochę ponad $14 \%$ respondentów wskazuje na taką współpracę. Pozytywny jest fakt wskazywania pracy oddanych nauczycieli, którzy umożliwiają spełnienie pokładanych $\mathrm{w}$ szkole oczekiwań. Pokazuje to, jak wiele zależy od zatrudnionego personelu pedagogicznego.

\section{Podsumowanie wyników badań i wnioski}

Z przeprowadzonej analizy zebranego materiału empirycznego wynika, iż rodzice decydują się posłać dziecko do konkretnej placówki z wielu zróżnicowanych powodów. Bardzo dużą rolę odgrywają czynniki lokalizacyjne szkoły - bliskość miejsca zamieszkania czy dobry dojazd. Również fakt kształcenia się przez inne dzieci danego rodzica $w$ tej samej placówce jest istotny. Niewątpliwe czynniki te są bezpośrednio związane $\mathrm{z}$ organizacją dnia $\mathrm{w}$ domu rodzinnym $-\mathrm{w}$ klasach młodszych $\mathrm{z}$ przyprowadzaniem/ odbieraniem ucznia, a w klasach starszych z samodzielnym pokonywaniem drogi do placówki edukacyjnej przez dziecko. Lokalizacja jest również ważne $\mathrm{z}$ tego względu, że integracja w szkole jest wprowadzeniem do integracji społecznej ${ }^{19}$. Co ważne, rodzice uwzględniają także opinie innych (zarówno znajomych, jak i innych rodziców).

${ }^{19}$ M. Chodkowska, dz. cyt., s. 29. 
Czynniki związane ogólnie z ideą integracji są przez rodziców deklarowane jako te, które decydowały o posłaniu dziecka do klasy integracyjnej. Są to przede wszystkim życzenia rodziców dotyczące tego, by dziecko umiało pomagać innym, traktowało wszystkich w sposób życzliwy, ale również problemy i trudności osób z niepełnosprawnością. Nie bagatelną rolę w opinii respondentów odegrały ich przekonania na temat równości wszystkich ludzi.

Odpowiedzi respondentów wskazują na wysoką świadomość rodziców zalet i wad placówki, do której uczęszcza ich dziecko. Respondenci zgłaszali bardzo wiele zróżnicowanych oczekiwań wobec szkoły i klasy, do której posłali dziecko. W większości zostały one uznane za niespełnione lub spełnione $\mathrm{w}$ minimalnym stopniu. Tym, oczekiwaniom natomiast, które zrealizowano przypisano głównie następujące przyczyny takiego stanu: pracującym w szkole oddanym nauczycielom i panującej dobrej atmosferze. Można przypuszczać, że te dwa elementy łączą się z sobą. Jak wykazała w swoich badaniach Jolanta Lipińska-Lokś, program zajęć wychowawczych oraz właściwa postawa nauczyciela mają wpływ na relacje emocjonalne między uczniami, w szczególności między uczniami z niepełnosprawnością a uczniami pełnosprawnymi20. Również inni badacze wskazuję na dużą rolę nauczyciela w stworzeniu warunków rozwoju dla każdego ucznia (w tym m.in. dostosowanie materiału i metod pracy do uczniów, kształtowanie tolerancji, motywacji do nauki oraz stwarzanie możliwości partnerskiego kontaktu między dziećmi $\left.{ }^{21}\right)$.

${ }^{20}$ J. Lipińska-Lokś, Zmiany stosunków między dziećmi petnosprawnymi i dziećmi $z$ niepetnosprawnościa w klasach integracyjnych, Uniwersytet Zielonogórski, Zielona Góra 2011, s. 194-213, 218.

${ }^{21}$ I. Rudek, Od niechęci do akceptacji. O wychowaniu dzieci do tolerancji wobec osób niepetnosprawnych, Oficyna Wydawnicza „Impuls”, Kraków 2007, s. 163-199; J. Bogucka, Petne uczestnictwo, [w:] J. Bogucka, M. Kościelska (red.), Wychowanie i nauczanie integracyjne, Społeczne Towarzystwo Oświatowe Bogucka, Warszawa 1994, s. 23; U. Burzyńska, W. Domański, Specyfika pracy wychowawcy w grupie integracyjnej, [w:] J. Bogucka, M. Kościelska (red.), Wychowanie $i$ nauczanie integracyjne, Społeczne Towarzystwo Oświatowe, Warszawa 1994, s. 122-123; A. Fidelus, Problem integracji 
Należy wskazać, iż o rodzaju kształcenia dzieci powinni decydować rodzice, ponieważ wdrażanie młodego pokolenia do realizacji idei integracji powinno odbywać się już w rodzinie. To właśnie opiekunowie mają ogromny wpływ na swoje dzieci, gdyż przekazują im wyznawane przez siebie wartości. $Z$ tego względu motywacja rodziców do posłania dziecka do klasy integracyjnej powinna być przemyślana i oparta na przekonaniu między innymi o równości wszystkich ludzi.

\section{Bibliografia}

BogucKa J., Petne uczestnictwo, [w:] J. Bogucka, M. Kościelska (red.), Wychowanie i nauczanie integracyjne, Społeczne Towarzystwo Oświatowe Bogucka, Warszawa 1994.

BURZYŃSKA U., DOMAŃSKI W., Specyfika pracy wychowawcy w grupie integracyjnej, [w:] J. Bogucka, M. Kościelska (red.), Wychowanie i nauczanie integracyjne, Społeczne Towarzystwo Oświatowe, Warszawa 1994.

CHODKOWSKA M., Razem damy sobie radę. $W$ drodze do zintegrowanego spoteczeństwa, WSiP, Warszawa 2009.

ĆWIRYNKAŁO K., Pozycja socjometryczna uczniów niepetnosprawnych a postawa nauczycieli wobec integracji, [w:] Z. Kazanowski, D. Osik-Chudowolska (red.), Integracja osób niepetnosprawnych w edukacji i integracjach społecznych, Wyd. Uniwersytetu Marii Curie-Skłodowskiej, Lublin 2003.

DRYŻAŁOWSKA G., Rozwój jezykowy dziecka z uszkodzonym stuchem a integracja edukacyjna. Model ksztatcenia integracyjnego, Wyd. Uniwersytetu Warszawskiego, Warszawa 2007.

FIDELUS A., Problem integracji dziecka niepetnosprawnego pochodzacego $z$ rodziny mieszkającej na wsi, [w:] Z. Kazanowski, D. Osik-Chudowolska (red.), Integracja osób niepetnosprawnych $w$ edukacji i interakcjach społecznych, Wyd. Uniwersytetu Marii Curie-Skłodowskiej, Lublin 2003.

dziecka niepetnosprawnego pochodzacego z rodziny mieszkajacej na wsi, [w:] Z. Kazanowski, D. Osik-Chudowolska (red.), Integracja osób niepetnosprawnych w edukacji i interakcjach społecznych, Wyd. Uniwersytetu Marii Curie-Skłodowskiej, Lublin 2003, s. 44; G. Dryżałowska, Rozwój jezzykowy dziecka z uszkodzonym stuchem a integracja edukacyjna. Model ksztatcenia integracyjnego, Wyd. Uniwersytetu Warszawskiego, Warszawa 2007, s. 111. 
GAJDZICA Z., Kategorie sukcesów w opiniach nauczycieli klas integracyjnych jako przyczynek do poszukiwania koncepcji edukacji integracyjnej, Oficyna Wydawnicza „Impuls", Kraków 2014.

GŁÓWNY URZĄD STATYSTYCZNY, Oświata i wychowanie w roku szkolnym 2013/2014, Zakład Wydawnictw Statystycznych, Warszawa 2014.

KAZANOWSKI Z., MAZUR B., Samoocena mtodzieży niepetnosprawnej intelektualnie w stopniu lekkim jako wyznacznik integracji społecznej, [w:] G. Dryżałowska, H. Żuraw (red.), Integracja społeczna osób niepetnosprawnych, Wyd. Akademickie "Żak", Warszawa 2004.

LIPIŃSKA-LOKŚ J., Zmiany stosunków między dziećmi petnosprawnymi i dziećmi z niepetnosprawnościa w klasach integracyjnych, Uniwersytet Zielonogórski, Zielona Góra 2011.

MIHILEWICZ S., Postrzeganie integracji przez rodziców dzieci sprawnych $i$ niepetnosprawnych, [w:] Z. Kazanowski, D. Osik-Chudowolska (red.), Integracja osób niepetnosprawnych w edukacji i integracjach społecznych, Wyd. Uniwersytetu Marii Curie-Skłodowskiej, Lublin 2003.

RAFAŁ-ŁUNIEWSKA J., Wspieranie dziecka ze specjalnymi potrzebami edukacyjnymi razem - rodzice i szkoła, Ośrodek Rozwoju Edukacji, Warszawa, <www.zsl-goraj.cil.pl/ dokumenty/wdsp.pdfpdf>, [dostęp: 28.05.2015].

ROGALIŃSKA M., „3D” w szkole masowej, a rzeczywistość, [w:] Z. Janiszewska-Nieścioruk (red.), Uczeń o specjalnych potrzebach edukacyjnych w przestrzeni wspótczesnego systemu edukacji, Oficyna Wydawnicza Uniwersytetu Zielonogórskiego, Zielona Góra 2010.

ROZPORZĄDZENIE MINISTRA EDUKACJI NARODOWEJ z dnia 21 maja $2001 \mathrm{r}$. w sprawie ramowych statutów publicznego przedszkola oraz publicznych szkół.

ROZPORZĄDZENIE MINISTRA EDUKACJI NARODOWEJ z dnia 2 sierpnia 2013 r. zmieniające rozporządzenie w sprawie warunków organizowania kształcenia, wychowania i opieki dla dzieci i młodzieży niepełnosprawnych oraz niedostosowanych społecznie w przedszkolach, szkołach i oddziałach ogólnodostępnych lub integracyjnych.

ROZPORZĄDZENIE MINISTRA EDUKACJI NARODOWEJ z dnia 17 listopada $2010 \mathrm{r}$. w sprawie warunków organizowania kształcenia, wychowania i opieki dla dzieci i młodzieży niepełnosprawnych oraz niedostosowanych społecznie w przedszkolach, szkołach i oddziałach ogólnodostępnych lub integracyjnych.

ROZPORZĄDZENIE MINISTERSTWA EDUKACJI NARODOWEJ z dnia 7 lutego 2012 r. w sprawie ramowych planów nauczania w szkołach publicznych.

RUDEK I., Od niechęci do akceptacji. O wychowaniu dzieci do tolerancji wobec osób niepetnosprawnych, Oficyna Wydawnicza „Impuls”, Kraków 2007.

TWARDOWSKI A., Dylematy integracyjnego ksztatcenia dzieci i młodzieży $z$ niepetnosprawnościa, [w:] Z. Janiszewska-Nieścioruk (red.), Problemy edukacji integracyjnej 
dzieci i młodzieży z niepetnosprawnościa intelektualna, Oficyna Wydawnicza „Impuls", Kraków 2007.

ZAMKOWSKA A., Modele wsparcia udzielanego uczniowi z niepetnosprawnościa w szkole inkluzyjnej - rozwiazania zagraniczne, [w:] Z. Janiszewska-Nieścioruk (red.), Uczeń o specjalnych potrzebach edukacyjnych w przestrzeni wspótczesnego systemu edukacji, Oficyna Wydawnicza Uniwersytetu Zielonogórskiego, Zielona Góra 2010.

ZAWADZKA D., Biblioteczka refleksyjnego praktyka. Nauczyciele i rodzice - sprzymierzeńcy $w$ edukacji $i$ wychowaniu, <http://www.praktykinauczycielskie.dsw.edu.pl/ wp-content/uploads/2011/03/Seminarium_D.Zawadzka_06_05.pdf>, [dostęp: 28.05.2015].

ŻYTA A., Szanse i zagrożenia integracyjnego ksztatcenia i bytowania osób z głębsza niepetnosprawnościa intelektualna, [w:] Z. Kazanowski, D. Osik-Chudowolska (red.), Integracja osób niepetnosprawnych w edukacji i integracjach społecznych, Wyd. Uniwersytetu Marii Curie-Skłodowskiej, Lublin 2003. 